\title{
Dendrochronology in Namibia: A Review
}

\author{
R N Shikangalah* \\ Department of Geography, University of Namibia, Namibia
}

Submission: April 03, 2020; Published: April 16, 2020

*Corresponding author: R N Shikangalah, Department of Geography, Faculty of Humanities and Social Sciences, University of Namibia, Private Bag 13301, Windhoek, Namibia

Abstract

More than $64 \%$ of Namibia's land is occupied by the savanna ecosystems which are vulnerable to climate change and variability. These ecosystems partly consist of forest ecosystem patches which are prime sources of many livelihoods in the country. The effects of climate change are likely to drive the majority of the country's population to poverty if these resources are not sustainably managed. Therefore an understanding of forest dynamics and their responses to climate is important. Dendrochronology is a study that provides time-series data of climate change and variability, and the responses of trees to such changes. The data are used to reconstruct past events of climate and also to forecast possibilities. Dendrochronological studies have been carried out in Namibia, however, a review of such studies is lacking. This study thus aimed at closing this gap and carried out a literature review on the dendrochronological studies in Namibia. The review showed that the field of dendrochronology is relatively new and has been less applied in Namibia. There is a need for further dendrochronological studies in order to understand how the country can adapt better under the current and forecasted climate regimes. A focus on the marginal forests, encroachers and trees that are of indigenous use, is recommended. In cases of the absence of clear ring formation, which might be the case in arid to hyper arid, the use of staple isotopes is recommended.

Keywords: Dendrochronology; Climatic conditions; Growth rings; Semiarid ecosystems; Namibia

\section{Introduction}

Dendrochronology studies have been used by ecologists worldwide to understand the vegetation and environmental conditions of the surrounding, as trees record past conditions. Trees are sensitive to environmental abiotic and biotic factors. Abiotic factors such as temperature (severity of dry seasons) and amount of rainfall are the most important to the development of the vegetation structure [1-4]. Sensitivity to abiotic factors can be used as a sensor or proxy for climate as various tree species respond to climatic variations differently in the formation of their annual tree-rings, especially in areas with distinct seasonality of rainfall [1,5-9]. These features are more pronounced in the Northern hemisphere compared to the Southern hemisphere. However, Southern hemisphere trees also possess growth rings that correlate with rainfall $[10,11]$.

Climatic conditions are characterised by erratic rainfall and recurring drought periods [12-14], reinforcing flood events, periods of drought and the rate at which evaporation might be occurring. Due to dry climate conditions that are so variable, the dense tropical forests, especially the indigenous forest, are becoming rare while bush encroachment is slowly taking over
$[15,16]$. Namibia is known for its remarkable variety of species and habitats and ecosystems and it is also recognised as a dryland with biodiversity hotspots [15]. However, they are greatly influenced by the variability of the climate regimes, thus making the ecosystems more vulnerable. Forest resources do not only contribute to the national economy, but they are also crucial for reducing poverty in the country. As a result of poor rainfall, there is an increase in poor cereal harvesting and a rise of land degradation has been reported [15]. The dating and reconstruction of long past periods from tree ring patterns to monitor vegetation growth and productivity during extreme climatic periods and specific events such as fire, and to also forecast the possible climate conditions in the country is therefore of utmost importance. Studies have been carried out in Namibia on tree rings and dating, relating to environmental conditions. However, there has not been a review of such studies in Namibia. This review paper therefore aimed at closing this gap by exploring the work done and outlining further dendrochronological opportunities in Namibia.

\section{Literature review}

The study of tree annual growth rings by dating the ring 
formation to specific years is known as dendrochronology. Several terminologies have stemmed from the concept of dendrochronology, depending on the issues to be studied. This includes terms such as dendroclimatology for particularly for looking into past climate variability $[17,18]$, dendroecology which is the broader science field for drawing environmental information from tree rings such as fires and insect outbreaks [19,20], dendrogeomorphology which is a subfield of dendroecology and focuses on geomorphological processes such as flooding, rock fall activities or landslides, and river related vegetation processes [21,22], and dendroarcheology which focuses on dating wooden material from archaeological sites [23,24]. Decdrochronology has also been used for studying snow avalanches, volcanoes eruptions and earthquakes [25].

The use of dendrochronological studies to understand various past environmental aspects is common and has been used for many decades around the world. According to Worbes [26], Hartig [27] has used it to look into the periodic wood formations in temperate regions, whereas Brandis [28] focused on sustainable silvicultural systems, and Coster [29] analysed the anatomical description of the woods [26]. The basic aspects, the applications and progress in technical developments have been explained and documented in various reviews (Rosendaal \& Zuidema 2011; Scweingruber 1988) [26,30-32]. In tropical regions of Africa, an increasing number of such studies have been carried by several scholars [2,911,33-35]. Despite the early arguments about the lack of distinct annual rings due to the absence of low temperatures and the presence of dormant winter seasons faced by trees in Southern Africa, particularly in tropical regions. Steenkamp, Vogel, Fuls, van Rooyen and van Rooyen [34] analysed some species and showed that trees are responsive to seasonal climate variations and this lead to the formation of annual growth tree rings.

\section{Methods and Materials}

\section{Settings}

Namibia is located in the South West part of Africa and occupies an areas of $825418 \mathrm{~km}$. The perennial rivers are only located at the borders, with Orange River at the South, Kunene at the North West while Kavango river and Zambezi river are the NorthEastern part of the country. The interior of the country consists of only non-perennial rivers. The average annual temperatures are observed to range from $16^{\circ} \mathrm{C}$ at the coast to $20^{\circ} \mathrm{C}$ and $22^{\circ} \mathrm{C}$ in the interior of the country (see Figure 1a) [36]. The maximum temperatures experienced are over $34^{\circ} \mathrm{C}$ and the minimum in the coldest months is less than $2^{\circ} \mathrm{C}$ [12]. The average annual rainfall varies from the coast with less than $250 \mathrm{~mm}$ to an average of $600 \mathrm{~m}$ in the areas with the most rainfall (Figure 1b). Of the total rainfall that the country receives, it is estimated that $83 \%$ of the rainfall evaporates, $14 \%$ ends up used by the vegetation, $2 \%$ goes to runoff and $1 \%$ recharges the groundwater [15,37]. Despite the fact that so much less rainfall contributes to groundwater recharge, around $80 \%$ of the country depends on the groundwater system. a)

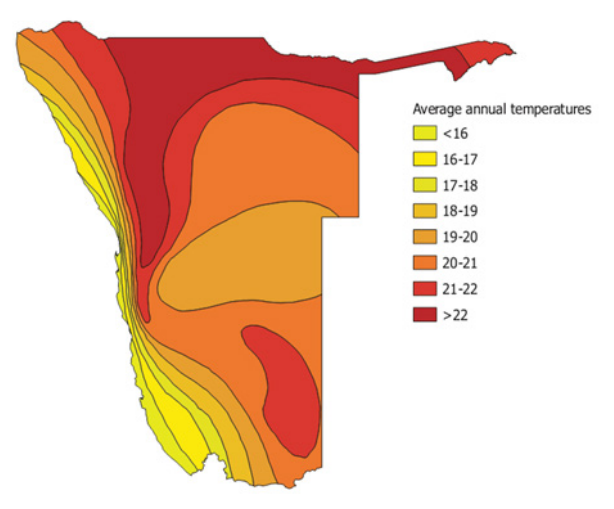

b)



Figure 1: a) Temperature, and b) Rainfall of Namibia [36].

In the last country census [38], the Namibian population was estimated to be 2.1 million, and the current population estimation is 2.5 million, making the country one of the least densely populated in the world, with 3.13 people per square kilometre [39]. Traditional subsistence sectors are responsible for providing for the livelihoods, with main activities including mining, tourism, fishing and agriculture and at least $70 \%$ of the population depends on agricultural activities $[40,41]$.
Arid to semiarid areas occupy at least $44 \%$ of the world land and these are responsible for nearly $38 \%$ of the global population [42-44]. These regions are climatically stressed by the limited rainfall, high temperatures and long dry seasons [45]. According to New [45], the mean temperature has increased by 0.25 degrees per decade since 1960 in Southern African semi-arid areas. Moreover, savanna trees, shrubs and grasslands cover most of the arid and semi-arid regions worldwide. Due to the sensitivity 
of vegetation growth to timing and variations in the local climate systems in Southern African tropical regions, savanna ecosystem functioning is greatly affected and in some parts of the region, the resultant changes are linked to decreased ecosystem productivity, thus land degradation $[10,46,47]$.

At least $20 \%$ of Namibia is occupied by a desert region, $33 \%$ is arid, $37 \%$ is semiarid and $8 \%$ is covered by a sub-humid region (see Figure 2a) [48,49]. In Namibia, savannah trees and shrubs which are dominated by Acacia vegetation occupy up to $64 \%$ of the land; savanna broadleaved dry woodlands and forests cover $20 \%$, and the desert region makes up $16 \%$ (Figure 2b) [50,51]. Forests around the country indicate that rare dense forests are generally scarce and they are described as dry, semi open to woodlands and these are largely located mostly in the deep Aeolian Kalahari sands (i.e. north-central-eastern part of the country) [54]. This is in spite of the fact that forest resources are used as a means to reduce poverty in communities around the country.

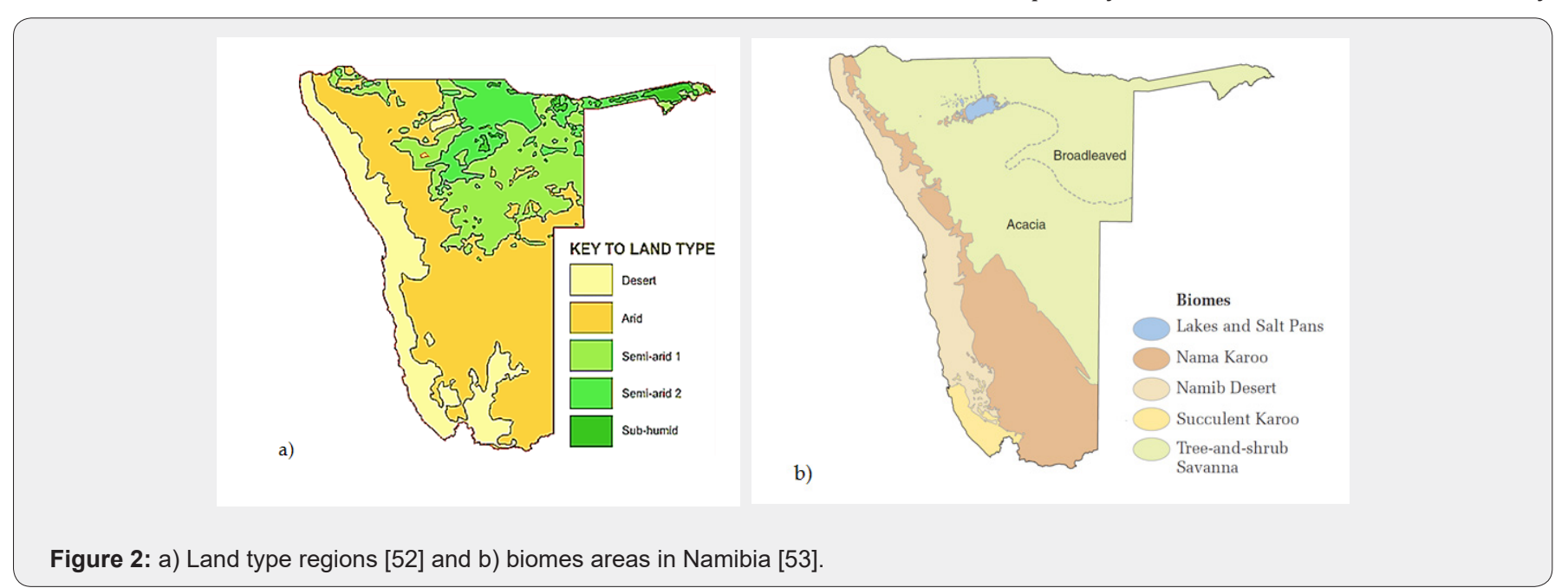

\section{Methods}

The methodology employed in this study is a literature review. First, the study provided a background and a time line of dendrochronology. Furthermore, the study presented the climatic, vegetation and population on the semi-arid savanna ecosystems as a way to provide a Namibian context. In the results section, the first part presents a summary of dendrochronological researches carried out in Namibia in relation to their methods, species analysed, regions covered and their findings in terms of the tree ring observables. The second part presents the forecasted climatic regimes to show the importance of dendrochronology studies in the country. This is important as the majority of the population depends on the vulnerable ecosystems, particularly on agricultural resources. Climate change affects natural resources, and this is projected to worsen in the future, especially in semiarid to arid regions [55]. The discussion drew from a context of climate change, the application of dendrochronology in Africa, and the need to focus on specific issues that are outlined to be of great concern in Namibia.

\section{Results}

\section{Studies on dendrochronology in Namibia}

A search for studies in dendrochronology yield eight studies that are carried out in Namibia (Table 1). The studies were mostly carried out from the central-northern Namibia, covering mostly a rainfall gradient from the Kunene, Oshikoto, Kavango West and
East, Zambezi and Otjozondjupa regions. Figure 3 shows how the ring rings are identified in one of the study. From these studies, sixteen (16) species of trees were examined and distinctive tree rings were successfully identified age determination was possible. These indicate that the species are responsive to climatic seasons. Using the staple-carbon isotope methodology, the trees showed responsiveness to inter-annual variability as two samples showed the same patterns (Figure 4). Climatic stress factors (wet and dry) induce the cambial dormancy and promote growth in woods [3]. This results in observable anatomical changes as the trees shed leaves and produce new leaves $[63,64]$. Large vessel zones are produced during the wet periods where water availability is in abundance, while the small vessel layers are defined by dry seasons due to the cambial activities being reduced under low water availability $[64,65]$. In addition to age determination, and analyses of growth rings responsiveness to precipitation, the latest study of tree rings in Namibia [56] also developed a master chronology for Dichrostachys cinerea and Senegalia (Acacia) mellifera, forming a basis for future dendrochronological studies of the two species in Namibia.

\section{Forecasted climate conditions}

New [45] carried out a study on the current state and modelled future climate conditions. Rainfall variability is evident within the last decades, with rainfall varying from $40 \%$ below and $70 \%$ above the average (Figure 5). Their results further showed faster increases in temperature over semi-arid areas in 
the future, indicating a warming rate of between 0.32 and 0.38 degrees per decade up to 2050 (Figure 6a) and projected trends ranging from 35 to $40 \%$ and higher than the warming for the wider Southern Africa region, which suggests that accelerated warming will become worse in the future, depending on future greenhouse gasses emissions. Their climate models also showed reduced total rainfall in the future; however, $25 \%$ of the model showed increased rainfall, which signifies rainfall variability in the future (Figure 6b). With specific reference to Namibia, rainfall is expected to decline with $10 \%$ in the southern part of the country and with $15 \%$ in the central regions [54]. For every $1 \%$ change in the rainfall, it is estimated that there will be $1.2 \%-1.6 \%$ changes in the carrying capacity, and around $1.3 \%$ changes in revenue from livestock farming [54]. Reduction on carrying capacity does not only affect the livestock, it also affects wildlife, tourism activities, and therefore livelihoods that directly and indirectly depend on it, and as well as the country's economy at large. A reduction on the rainfall also means less harvests from traditional subsistence farming which supports around 70\% of the country's population.

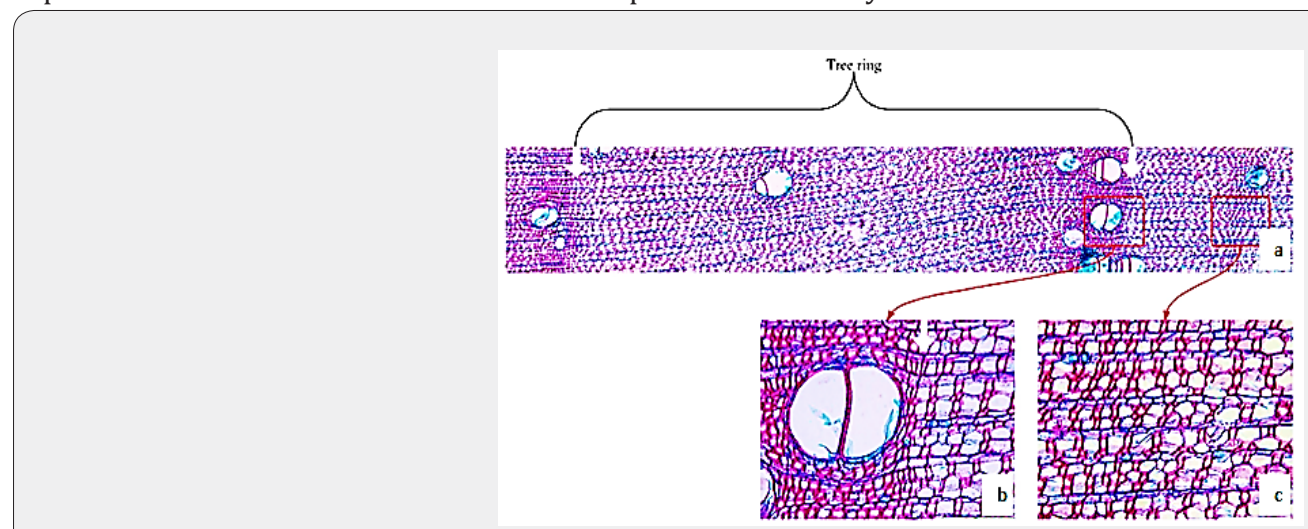

Figure 3: Micro images from Schinziophyton rautanenii from Kavango West region: a) entire ring at $25 \mathrm{x}$ magnification, b) a ring boundary at $100 x$ magnification, and c) a false ring at 100x magnification [59].



Figure 4: Inter- annual variability of $\delta 13 C$ profile of Terminalia sericea Terse 34 (older sample) \& Terse 43 (younger sample) from Zambezi region [60].

Table 1: Studies on dendrochronology in Namibia.

\begin{tabular}{|c|c|c|c|c|c|c|c|}
\hline Year & Title & Authors & $\begin{array}{l}\text { Regions of } \\
\text { Study Area }\end{array}$ & Method & Analysed Trees & Rings & Conclusion \\
\hline 2020 & $\begin{array}{c}\text { Growth ring formation } \\
\text { of Dichrostachys cinerea } \\
\text { and Senegalia mellifera } \\
\text { in arid environments in } \\
\text { Namibia }\end{array}$ & $\begin{array}{l}\text { Shikangalah, } \\
\text { Mapani, Ma- } \\
\text { paure, Herz- } \\
\text { schuh, Musimba } \\
\text { and Tabares [56] }\end{array}$ & $\begin{array}{l}\text { Oshikoto, } \\
\text { Otjozondjupa, } \\
\text { Omaheke }\end{array}$ & $\begin{array}{l}\text { Growth rings on } \\
\text { stem discs and } \\
\text { their variability } \\
\text { along rainfall } \\
\text { gradient }\end{array}$ & $\begin{array}{c}\text { Dichrostachys cinerea } \\
\text { and Senegalia (Aca- } \\
\text { cia) mellifera }\end{array}$ & Yes & $\begin{array}{l}\text { Distinctive rings } \\
\text { observed and } \\
\text { responsive to } \\
\text { precipitation, } \\
\text { patterns more } \\
\text { clear in } D \text {. } \\
\text { cinerea than } S \text {. } \\
\text { mellifera. Can be } \\
\text { used as proxies } \\
\text { for climate } \\
\text { signals. }\end{array}$ \\
\hline
\end{tabular}




\section{International Journal of Environmental Sciences \& Natural Resources}

\begin{tabular}{|c|c|c|c|c|c|c|c|}
\hline 2017 & $\begin{array}{l}\text { Determining age, } \\
\text { growth rate and } \\
\text { regrowth for a few tree } \\
\text { species causing bush } \\
\text { thickening in north } \\
\text { central Namibia }\end{array}$ & $\begin{array}{c}\text { Cunningham \& } \\
\text { Detering [57] }\end{array}$ & $\begin{array}{l}\text { Kunene, Oshiko- } \\
\text { to, Otjozondjupa } \\
\text { region }\end{array}$ & $\begin{array}{l}\text { Growth rings on } \\
\text { stem discs }\end{array}$ & $\begin{array}{l}\text { Acacia fleckii, Acacia } \\
\text { reficiens, Acacia } \\
\text { mellifera, Acacia } \\
\text { tortillis, Colophos- } \\
\text { permum mopane, } \\
\text { Combretum apicula- } \\
\text { tum, Dichrostachys } \\
\text { cinerea, Terminalia } \\
\text { prunioides }\end{array}$ & Yes & $\begin{array}{c}\text { Distinctive rings } \\
\text { observed }\end{array}$ \\
\hline 2017 & $\begin{array}{l}\text { Predicting site produc- } \\
\text { tivity of the timber tree } \\
\text { Pterocarpus angolensis }\end{array}$ & $\begin{array}{c}\text { De Cauwer et al. } \\
{[58]}\end{array}$ & $\begin{array}{l}\text { Kavango West, } \\
\text { Otjozondjupa }\end{array}$ & $\begin{array}{l}\text { Growth rings on } \\
\text { stem discs and } \\
\text { cores }\end{array}$ & $\begin{array}{c}\text { Pterocarpus ango- } \\
\text { lensis }\end{array}$ & Yes & $\begin{array}{l}\text { Distinctive rings } \\
\text { observed and } \\
\text { might be useful } \\
\text { for climate } \\
\text { signals at local } \\
\text { scale. }\end{array}$ \\
\hline 2016 & $\begin{array}{c}\text { Annual diameter } \\
\text { growth of Pterocarpus } \\
\text { angolensis (kiaat) and } \\
\text { other woodland species } \\
\text { in Namibia. }\end{array}$ & $\begin{array}{l}\text { Van Holsbeeck, } \\
\text { De Cauwer, De } \\
\text { Ridder, Fitchtler, } \\
\text { Beeckman, \& } \\
\text { Mertens [59] }\end{array}$ & $\begin{array}{c}\text { Oshikoto, } \\
\text { Kavango West, } \\
\text { Kavango East, } \\
\text { Zambezi region }\end{array}$ & $\begin{array}{l}\text { Growth rings on } \\
\text { cores and stem } \\
\text { discs }\end{array}$ & $\begin{array}{l}\text { Pterocarpus ango- } \\
\text { lensis, Terminalia } \\
\text { sericea, Baikiaea } \\
\text { plurijuga, Burkea } \\
\text { africana, Schinzio- } \\
\text { phyton rautanenii }\end{array}$ & Yes & $\begin{array}{l}\text { Distinctive rings } \\
\text { observed }\end{array}$ \\
\hline 2010 & $\begin{array}{l}\text { Staple-carbon isotope } \\
\text { time series from tropi- } \\
\text { cal tree rings indicate a } \\
\text { precipitation signal }\end{array}$ & $\begin{array}{l}\text { Fichtler, Helle, \& } \\
\text { Worbes [60] }\end{array}$ & Zambezi region & $\begin{array}{l}\text { Growth rings on } \\
\text { stem discs and } \\
\text { inter -annual } \\
\text { analysis of vari- } \\
\text { ability }\end{array}$ & Terminalia sericea & Yes & $\begin{array}{c}\text { Distinctive } \\
\text { rings observed, } \\
\text { inter-annual } \\
\text { variability clear }\end{array}$ \\
\hline 2007 & $\begin{array}{l}\text { Radiocarbon dating } \\
\text { of a very large African } \\
\text { baobab }\end{array}$ & Patrut et al. [61] & Otjozondjupa & $\begin{array}{l}\text { Age determination } \\
\text { by radiocarbon } \\
\text { dating }\end{array}$ & Adansonia digitata & $\mathrm{N} / \mathrm{A}$ & $\begin{array}{c}\text { Tree older than } \\
1200 \text { years }\end{array}$ \\
\hline 2004 & $\begin{array}{l}\text { Climatic signals in tree } \\
\text { of Burkea africana and } \\
\text { Pterocarpus angolensis } \\
\text { from semiarid forests in } \\
\text { Namibia }\end{array}$ & $\begin{array}{c}\text { Fichtler, Trouet, } \\
\text { Beeckman, } \\
\text { Coppin \& Worbes } \\
{[10]}\end{array}$ & $\begin{array}{l}\text { Oshikoto \& Zam- } \\
\text { bezi region }\end{array}$ & $\begin{array}{l}\text { Growth rings on } \\
\text { stem disc }\end{array}$ & $\begin{array}{l}\text { Pterocarpus angolen- } \\
\text { sis, Burkea africana }\end{array}$ & Yes & $\begin{array}{l}\text { Strong respons- } \\
\text { es to relative } \\
\text { humidity and } \\
\text { temperature } \\
\text { at Ondangwa. } \\
\text { At Katima only } \\
\text { angolensis is } \\
\text { more respon- } \\
\text { sive to climate } \\
\text { variables. }\end{array}$ \\
\hline 1999 & $\begin{array}{l}\text { Growth of Trees from } \\
\text { Namibia- A Dendro- } \\
\text { chronology Study }\end{array}$ & Worbes [62] & $\begin{array}{l}\text { Oshikoto, Zam- } \\
\text { bezi region }\end{array}$ & $\begin{array}{l}\text { Growth rings on } \\
\text { stem disc and ra- } \\
\text { diocarbon dating }\end{array}$ & $\begin{array}{l}\text { Pterocarpus ango- } \\
\text { lensis, Terminalia } \\
\text { sericea, Baikiaea } \\
\text { plurijuga, Burkea } \\
\text { africana, Colophos- } \\
\text { permum mopane, } \\
\text { Combretum collinum, } \\
\text { Lonchocarpus nelsii }\end{array}$ & Yes & $\begin{array}{l}\text { Distinctive } \\
\text { rings observed, } \\
\text { Terminelia } \\
\text { sericea hashigh } \\
\text { increment in } \\
\text { Katima but low } \\
\text { at Oshikoto }\end{array}$ \\
\hline
\end{tabular}

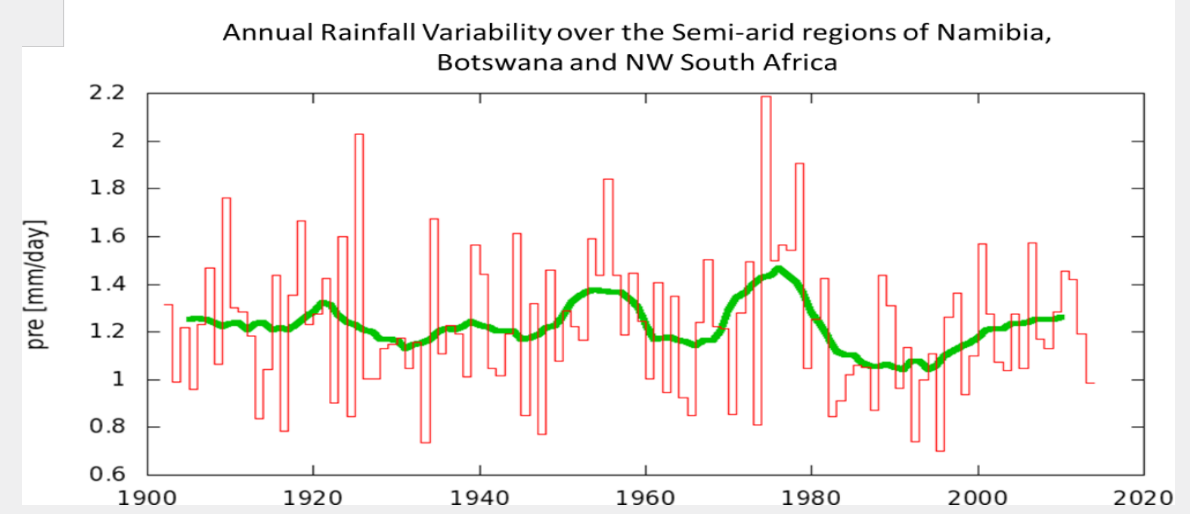

Figure 5: Annual rainfall variability over semi-arid of Namibia, Botswana and North-west South Africa [45]. 
a)

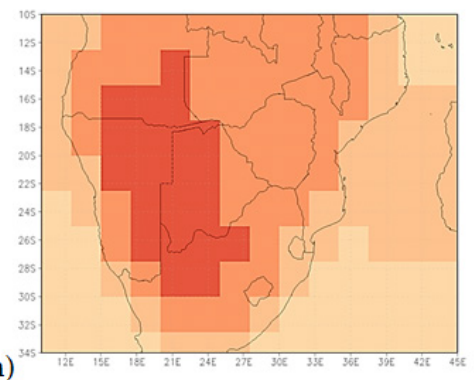

b)

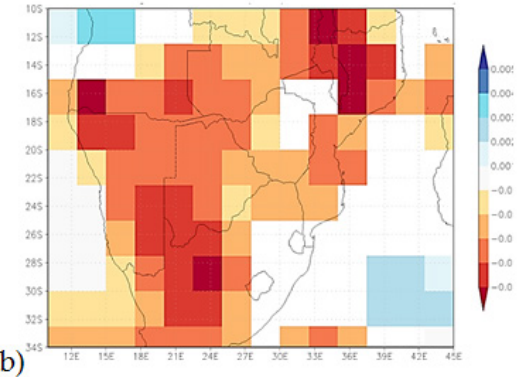

Figure 6: Regional climate forecasted trends out to 2050: a) temperature, and b) rainfall [45].

\section{Discussion}

According to Gebrekirstos et al. [30], the application of dendrochronology in Africa is mostly for the reconstruction of climate change history, extreme events, geomorphological related events, and this can also be used to assess the feedback systems, teleconnections, impacts on growth and resilience of species (Figure 7). This in the end gives quantified changes that can be used to make decisions on adaptations, mitigations and sustainable management of the resources.
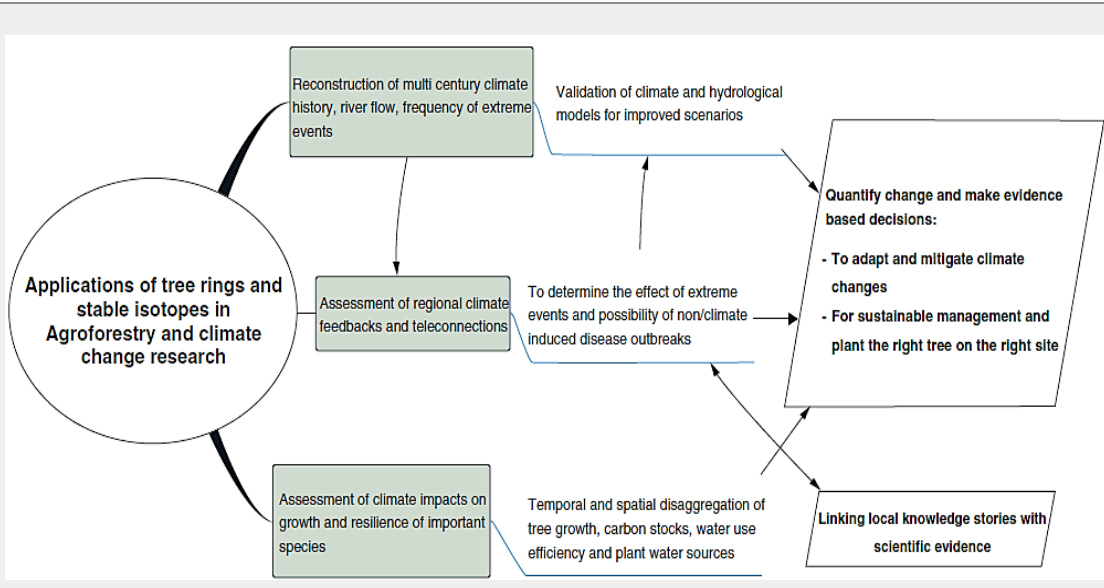

Figure 7: Possible application of dendrochronology in Africa [31].

The above outline application of dendrochronology is significant to Namibia. This is because climate change, global warming and rainfall variability, especially when it comes to the reduction of rainfall, have great impacts on the Namibian vulnerable recourses. First, the high temperatures promote more aridity conditions; the variability either leads to flooding events or drought periods. In addition, the various resources (water such as the groundwater system, water from surface flow; agriculture and land use including settlements areas) are significantly vulnerable to these conditions. The ecosystems are highly marginal and any relatively small changes are likely to lead to the systems to go beyond the limit point of viability, may may lead to a possibility of irreversible conditions.

Namibian forests are rare and found largely along riverbanks and mostly on remote locations. These forests support the majority of livelihoods in the country, especially in rural communities. They are also a way of "healing the dryland and protecting them from desertification and droughts" [54]. The use of dendrochronology to understand their responses to climate variability Could yield evidence based that can be used to understand their adaptation strategies and resilience mechanisms. Based on Table 1 species such as Pterocarpus anglensis and Terminelia sericea are more responsive to climate signals in Oshikoto region [10] and in Zambezi region [62,64], respectively. However, the ring growth were much better in Oshikoto region than in Zambezi region. It is less understandable for the former species to have better growth ring in Oshikoto region with less rainfall than in the Zambezi region with high rainfall amount and as temperatures are more or less the same in the two regions. Therefore, other factors such as soil and root structures have to be understood in studying dendrochronology, to be able to set up proper sustainable strategies in areas of concern. 
Acacia mellifera (Senegalia mellifera) and Dichrostachys cinerea are the most aggressive encroachers and are furthermost widely distributed encroachers in rangelands in Namibia [66-68]. They are responsible for nearly $40 \%$ of the encroached lands in rangelands and at least 15 million hectares in communal lands [69-73]. Increased temperature favours the encroachers such as A. mellifera due to their tap roots system that can tap onto deep moisture during drought period [74,75] and the increased carbon dioxide concentration in the atmosphere also favours them due to their $\mathrm{C}_{3}$ - photosynthetic systems that fixed carbon in elevated $\mathrm{CO}_{2}$ conditions $[76,77]$. That results in less loss of energy through photorespiration, therefore fast growth and recuperation from damages $[78,79]$. The impacts of encroachers are greatly affecting savanna ecosystems, biodiversity and groundwater systems, and even contributing to desertification $[66,80,81]$. Based on Table 1 , only two dendrochronology study has focused on the aggressive encroachers through analysing the growth rings and showed that they are responsive to precipitation and could be used for climatic signals. Studies using these species are therefore needed to reconstruct long period of climatic conditions.

\section{Conclusion}

A literature review on dendrochronology studies shows that the field of dendrochronology is relatively new and less applied in Namibia. This is in spite of the country being one of the most arid in the Southern Africa region, which makes the ecosystems most highly vulnerable the effect of climate change. This is worrisome when considering that such effects eventually impact livelihoods due to their high dependence on agriculture resources. The need for dendrochronology studies is therefore critical to understand the long, past and possible future environmental dynamics relating to the various resource the country depends on. Time series data analysis is necessary to understand their adaptation systems in relation to the climatic conditions, and understand forest ecosystems. The study recommends a focus on the marginal forest resources, further researches on encroachers to possibly save the drylands and trees that of indigenous use in Namibia.. There is high potential to expand the understanding on the species used by past studies as many of them were limited to a few areas and regions, and to a few (16) species. Vegetation need to be understood, especially in arid and hyper-arid areas such as around and in urbanised landscapes for sustainable management and planning of urban forests; along river banks (especially the ephemeral rivers as they support at least one-fifth of the Namibian population); in conservancies and other human- wildlife environments and lastly in areas of agricultural importance and communal lands where indigenous trees are vital to livelihoods. Clear ring formation growth ring determination might be difficult in the arid to hyper-arid environments, therefore the use of staple isotopes from cellulose to reconstruct past climate regimes, is recommended. Another method is the use of xylem anatomical features. This method focuses on functioning, growth and climaticgrowth interactions, therefore providing information on most tree resistant to the impacts of climate change.

\section{References}

1. Nicolini G, Tarchiani V, Saurer M, Cherubini P (2010) Wood-growth zones in Acacia seyal Delile in the Keita Valley, Niger: Is there any climatic signal? Journal of Arid Environments 74(3): 355-359.

2. Shorrocks B, Bates W (2015) The biology of African savannahs. Oxford, UK: Oxford University Press.

3. Trouet V, Coppin P, Beeckman H (2006) Annual growth ring Patterns in Brachystegia spiciformis reveal influence of precipitation on tree growth. Biotropica 38(3): 375-382.

4. Ratzmann G, Gangkofner U, Tietjen B, Fensholt R (2016) Dryland vegetation functional response to altered rainfall amounts and variability derived from satellite time series data. Remote Sensing 8(12): 10-26.

5. Cook E, Kairiukstis L (1990) Methods of dendrochronology Applications in the Environmental Sciences. Springer Science \& Business Media.

6. Meko D, Stockton CW, Boggess W (1996) The tree ring record of severe sustained drought. Water Resources Bulletin, American Water Resources Association 31(5): 789-824.

7. Sarris D, Christodoulakis D, Körner C (2007) Recent decline in precipitation and tree growth in the eastern Mediterranean. Global Change Biology 13(6): 1187-1200.

8. Pirie MR, Triggs CM, Fowler AM (2015) Concordance: A Measure of Similarity between Matrices of Time Series with Applications in Dendroclimatology. Journal of Agricultural, Biological, and Environmental Statistics 20(2): 258-278.

9. Zacharias M, Weijers S, Löffler J (2018) Growth rings in bush species of the South African savannah. African Journal of Ecology 56(2): 399-403.

10. Fichtler E, Trouet V, Beeckman H, Coppin P, Worbes M (2004) Climatic signals in tree rings of Burkea africana and Pterocarpus angolensis from semiarid forests in Namibia. Trees 18: 442-451.

11. Trouet V, Esper J, Beeckman H (2010) Climate / growth relationships of Brachystegia spiciformis from the miombo woodland in south central Africa. Dendrochronologia 28(3): 161-171.

12. Turpie AJ, Midgley G, Brown C, Barnes J, Pallett J, et al. (2010) Climate change vulnerability and adaptation assessment for Namibia's biodiversity and protected. Windhoek, Namibia: Ministry of Environment and Tourism, Directorate of Parks \& Wildlife Management.

13.Zimmermann M, Jokisch A, Deffner J, Brenda M, Urban W (2012) Stakeholder participation and capacity development during the implementation of rainwater harvesting pilot plants in central northern Namibia. Water Supply 12(4): 540-548.

14. Shikangalah RN, Mapani BS (2019) Precipitation variations and shifts over time: Implication on Windhoek city water supply. Physics and Chemistry of the Earth 112: 103-112.

15. Ministry of Environment and Tourism (MET) (2010) National policy on climate change for Namibia. Windhoek, Namibia: Ministry of Environment and Tourism.

16. Namibia Nature Foundation (NNF) (2016) An assessment of the economics of land degradation related to bush encroachment in Namibia. Windhoek, Namibia: Namibia Nature Foundation

17. Batranin AV, Bondarenko SL, Kazaryan MA, Krasnykh AA, Miloichikova IA, et al. (2019) Evaluation of the effect of moisture content in the wood sample structure on the quality of tomographic x-ray studies of tree rings of stem wood. Bulletin of the Lebedev Physics Institute 46(1): 16-18. 
18. de Vasconcellos TJ, Tomazello-Filho M, Callado CH (2019) Dendrochronology and dendroclimatology of Ceiba speciosa (A. St.Hil.) Ravenna (Malvaceae) exposed to urban pollution in Rio de Janeiro city, Brazil. Dendrochronologia 53: 104-113.

19. das Neves Brandes AF, Albuquerque RP, Domingues GDAF, Barros CF, Durigan G, et al. (2019) Dendroecology of Pinus elliottii Engelm. reveals waves of invasion in a neotropical savanna. Biological Invasions 21(181): 1-17.

20. Manzanedo RD, Pederson N (2019) Towards a more ecological dendroecology. Tree-Ring Research 75(2): 152-159.

21. Franco-Ramos O, Stoffel M, Ballesteros-Cánovas JA (2019) Reconstruction of debris-flow activity in a temperate mountain forest catchment of central Mexico. Journal of Mountain Science 16(9): 20962109.

22. Mainieri R, Lopez-Saez J, Corona C, Stoffel M, Bourrier F, et al. (2019) Assessment of the recurrence intervals of rockfall through dendrogeomorphology and counting scar approach: A comparative study in a mixed forest stand from the Vercors massif (French Alps). Geomorphology 340: 160-171.

23. Benzaquen M, Finkelstein I, Langgut D (2019) Vegetation history and human impact on the environs of Tel Megiddo in the bronze and iron ages: A dendroarchaeological analysis. Tel Aviv-Yafo 46(1): 42-64.

24. Boswijk G, Johns D, Hogg A (2019) Dendroarchaeology in New Zealand: Extending the range of archaeologically useful species beyond kauri (Agathis australis). Journal of Pacific Archaeology 10(1): 33-44.

25. Stoffel M (2006) A review of studies dealing with tree rings and rockfall activity: The role of dendrogeomorphology in natural hazard research Natural Hazards 39(1): 51-70.

26. Worbes M (2002) One hundred years of tree-ring research in the tropics-a brief history and an outlook to future challenges. Dendrochronologia 20(1-2): 217-231.

27. Hartig T (1853) Ueber die Entwicklung des Jahrringes der Holzpflanzen. Botanische Zeitschrift 3: 553-560.

28. Brandis D (1898) Forsteinrichtung in den Teakwaldungen von Pegu. Allgemeine Forst und Jagdzeitung 74: 45-52.

29. Coster C (1928) Zur Anatomie und physiologie der zuwachszonen und jahresringbildung in den tropen II. Annales du Jardin botanique de Buitenzorg 38: 1-114.

30. Fritts HC (1976) Tree rings and climate. New York, NY: Academic Press.

31. Gebrekirstos A, Bräuning A, Sass-Klassen U, Mbow C (2014) Opportunities and applications of dendrochronology in Africa. Current Opinion in Environmental Sustainability 6(1): 48-53.

32. Rahman M, Islam M, Wernicke J, Bräuning A (2018) Changes in Sensitivity of Tree-Ring Widths to Climate in a Tropical Moist Forest Tree in Bangladesh. Forests 9(12): 19-22.

33. Bhugeloo A (2014) Assessing the dendrochronological and dendroclimatological potential of Acacia nilotica (L.) in northern KwaZulu - Natal. Pietermaritzburg, SA: University if Kwazulu-Natal.

34. Steenkamp CJ, Vogel JC, Fuls A, Rooyen N Van, Rooyen MW Van (2008) Age determination of Acacia erioloba trees in the Kalahari. Journal of Arid Environments 72(4): 302-313.

35. Stahle DW, Mushove PT, Cleaveland MK, Roig F, Haynes GA (1999) Management implications of annual growth rings in Pterocarpus angolensis from Zimbabwe. Forest Ecology and Management 124(23): 217-229.

36. Mendelsohn R, Emanuel K, Chonabayashi S, Bakkensen L (2012) The impact of climate change on global tropical cyclone damage. Nature climate change 2(3): 205-209.
37. Nam Water (2019) Hydrological services. Namibia Water Corporation LTD. Windhoek, Namibia.

38. World Population Prospects (2019) Revision - United Nations population estimates and projections.

39. National Statistics Agency (2011) Namibia 2011 Population and Housing Census Preliminary Results. Windhoek, Namibia: National Statistics Agency.

40. Bank of Namibia (2017) $18^{\text {th }}$ annual symposium Feeding Namibia: agriculture productivity and industrialisation.

41. FAO (2019) Namibia at glance.

42. Huang CY, Archer SR, McClaran MP, Marsh SE (2018) Shrub encroachment into grasslands: End of an era? Peer J 6: e5474.

43. Yang Y, Bai L, Wang B, Wu J, Fu S (2019) Reliability of the global climate models during 1961-1999 in arid and semiarid regions of China. Science of the Total Environment 667(1): 271-286.

44. Trejo-Calzada R, Pedroza-Sandoval A, Arreola-Avila JG, García-González F (2019) Native plants to arid areas: A genetic reservoir for droughttolerant crops.

45. New M (2015) Are semi-arid regions climate change hot-spots? Evidence from Southern Africa. Adaptation at Scale in Semiarid Regions (ASSAR).

46. Ringrose S, Matheson W, Tempest F, Boyle T (1990) The development and causes of range degradation features in southeast Botswana using multi-temporal Landsat MSS imagery. Photogrammetric engineering and remote sensing (USA).

47. Southworth J, Rigg L, Gibbes C, Waylen P, Zhu L, et al. (2013) Integrating dendrochronology, climate and satellite remote sensing to better understand savanna landscape dynamics in the Okavango delta, Botswana. Land 2(4): 637-655.

48. National Drought Task Force (1997) Towards a drought policy for Namibia. A discussion document prepared by the National Drought Task Force for a workshop at Neudamm Agricultural College 11-13 March 1997. Windhoek, Namibia: National Drought Task Force.

49. United Nations Framework Convention on Climate Change (UNFCCC) (2010) Namibia second national communication to the United Nations framework convention on climate change. Windhoek, Namibia: Republic of Namibia

50.FAO (2003) Role of planted forests and trees outside forests in sustainable forest management in the Republic of Namibia. In: Thomas I, Chakanga M (Eds.), Planted Forests and Trees Working Papers, Working Paper 30. Forest Resources Development Service, Forest Resources Division. FAO, Rome, Italy.

51. Vrabcová P, Nikodemus A, Hájek M (2019) Utilization of forest resources and socio-economic development in Uukolonkadhi community forest of Namibia. Acta Universitatis Agriculturae et Silviculturae Mendelianae Brunensis 67(1): 197-206.

52. Mtuleni V (2019) Comprehensive environmental plan for road transportation of sulphuric acid along Trans-Zambezi (Walvis BayWenela Border). Walvis bay, Namibia: Ministry of Environment and Tourism.

53. Mendelsohn J, Jarvis A, Roberts C, Robertson T (2002) Atlas of Namibia: A portrait of land and its people.

54. United Nations Development Program (UNDP) (2019) Report on sustainable management of Namibia's forested lands (NAFOLA). UNDP-GEF project, 2014-2019.

55. IPCC (2007) Climate change 2007: Impacts, adaptation and vulnerability. Summary for policymakers. Working Group II Contribution to the Intergovernmental Panel on Climate Change. Fourth Assessment Report. 
56. Shikangalah R, Mapani B, Mapaure I, Herzschuh U, Musimba A, et al. (2020) Growth ring formation of Dichrostachys cinerea and Senegalia mellifera in arid environments in Namibia. Dendrochronologia 59: 125661.

57. Cunningham PL, Detering F (2017) Determining age, growth rate and regrowth for a few tree species causing bush thickening in northcentral Namibia. Namibian Journal of Environment 1(A): 72-76.

58. De Cauwer V, Fichtler E, Beeckman H, Graz FP, Mertens J, et al. (2017) Predicting site productivity of the timber tree Pterocarpus angolensis. Southern Forests: Journal of Forest Science 79(3): 259-268.

59. Van Holsbeeck S, De Cauwer V, De Ridder M, Fichtler E, Beeckman $\mathrm{H}$, et al. (2016) Annual diameter growth of Pterocarpus angolensis (Kiaat) and other woodland species in Namibia. Forest Ecology and Management 373: 1-8.

60. Fichtler E, Helle G, Worbes M (2010) Stable-carbon isotope time series from tropical tree rings indicate a precipitation signal. Tree-Ring Research 66(1): 35-50.

61. Patrut A, Von Reden KF, Lowy DA, Alberts AH, Pohlman JW, et al. (2007) Radiocarbon dating of a very large African baobab. Tree Physiology 27(11): 1569-1574.

62. Worbes M(1999b) Growth oftrees from Namibia.A dendrochronological study. Windhoek, Namibia: Namibia-Finland Forestry project.

63. Gourlay ID (1995) Growth ring characteristics of some African acacia species. Journal of Tropical Ecology 11(1): 121-140.

64. Worbes M (1999a) Annual growth rings, rainfall-dependent growth and long-term growth patterns of tropical trees from the Caparo forest reserve in Venezuela. Journal of Ecology 87(3): 391-403.

65. Nath CD, Munoz F, Pélissier R, Burslem DFRP, Muthusankar G (2016) Growth rings in tropical trees: Role of functional traits, environment, and phylogeny. Trees - Structure and Function 30(6): 2153-2175.

66. de Klerk J (2004) Bush encroachment in Namibia: Report on Phase 1 of the bush encroachment research, monitoring, and management project. Windhoek, Namibia: Ministry of Environment and Tourism, Directorate of Environmental Affairs.

67. Joubert DF, Rothauge A, Smit GN (2008) A conceptual model of vegetation dynamics in the semiarid Highland savanna of Namibia, with particular reference to bush thickening by Acacia mellifera. Journal of Arid Environments 72(12): 2201-2210.

68. Strohbach BJ (2000) Vegetation degradation trends in the northern Oshikoto Region: III. The Terminalia prunioides woodlands and Andoni grasslands. Dinteria 26: 76-92.

69. Bester FV (1999) Major problem, bush species and densities in Namibia. Agricola 10: 1-3.
70. Curtis BA, Mannheimer CA (2005) Tree atlas of Namibia. Windhoek, Namibia: National Botanical Research Institute, Ministry of Agriculture, Water and Forestry.

71. Hauwanga WN, McBenedict B, Strohbach BJ (2018) Trends of phanerophyte encroacher species along an aridity gradient on Kalahari sands, central Namibia. European Journal of Ecology 4(2): 4-47.

72. Marais E, Scott L, Gil-Romera G, Carrión JS (2015) The potential of palynology in fossil bat-dung from Arnhem cave, Namibia. Transactions of the Royal Society of South Africa 70(2): 109-115.

73. Ministry of Agriculture, Water and Forestry (MAWF) (2017) Animal Feed from Namibian Encroacher Bush. Windhoek, Namibia: Ministry of Agriculture, Water and Forestry.

74. Liu F, Archer SR, Gelwick F, Bai E, Boutton TW, et al. (2013) Woody plant encroachment into grasslands: Spatial patterns of functional group distribution and community development. PLoS ONE 8(12): e84364.

75. Nesongano W (2018) The effects of climate change, land-use and elevated carbon dioxide on tree-grass interactions in southern African savannas. Universät Tübingen, Germany.

76. Bond W, Woodward FI, Midgley GF (2002) Does elevated ${ }_{\mathrm{CO}}$ play a role in bush encroachment? In: Seydach AHW, Vorster T, Vermeulen WJ, van der Merwe IJ (Eds.), Multiple use management of natural forests and woodlands: Policy refinement and scientific progress. Pretoria, South Africa: Department of Water Affairs and Forestry, pp. 202-208.

77. Ministry of Agriculture, Water and Forestry (MAWF) (2014) Baseline Assessment for the De-Bushing Programme in Namibia. Windhoek, Namibia: Ministry of Agriculture, Water and Forestry.

78. Bond WJ, Midgley GF (2000) A proposed $\mathrm{CO}_{2}$-controlled mechanism of woody plant invasion in grasslands and savannas. Global Change Biology 6(8): 865-869.

79. Polley HW, Mayeux HS, Johnson HB, Tischler CR (1997) Viewpoint: Atmospheric $\mathrm{CO}^{*}$, soil water, and shrub/grass ratios on rangelands. Journal Range Management 50(3): 278-284.

80. Lukomska N, Quaas MF, Baumgärtner S (2014) Bush encroachment control and risk management in semi-arid rangelands. Journal of Environmental Management 145: 24-34.

81. Ward D, Esler KJ (2011) What are the effects of substrate and grass removal on recruitment of Acacia mellifera seedlings in a semi-arid environment? Plant Ecology 212(2): 245-250.

Your next submission with Juniper Publishers
will reach you the below assets
- Quality Editorial service
- Swift Peer Review
- Reprints availability
- E-prints Service
- Manuscript Podcast for convenient understanding
- Global attainment for your research
- Manuscript accessibility in different formats
( Pdf, E-pub, Full Text, Audio)
- Unceasing customer service
Track the below URL for one-step submission
https://juniperpublishers.com/online-submission.php

